\title{
NEW TRENDS ON THE FUTURE OF SOCIAL SECURITY LAW IN THE EUROPEAN UNION
}

\author{
Professor Dan Ţop \\ Valahia University of Târgoviște, Romania \\ Email: top.dan@gmail.com
}

\begin{abstract}
Creation of an European pillar of social rights was structured around three main themes, being identified as a range of policy areas, to which are attached different principles. All these guidelines are based on specific principles of guiding their applicability and concretely implemented in various documents. Once established, the pillar should become a frame of reference for verifying social performance and employment of the workforce participating Member States, to stimulate national reforms. We propose an analysis of the most relevant principles for European pillar of social rights, without claiming to exhaust the whole problem. This study leads to the conclusion that modern social policies should be based on investment in human capital, based on equality, prevention and protection against social risks, availability of safety devices and effective incentives to access market workforce.
\end{abstract}

Keywords: European Pillar of Social Rights; Social Policy; Specific Principles.

\section{Introduction}

On 9 September, 2015 the President U.E. Jean-Claude Juncker announced the creation of a European pillar of social rights. Social rights are also recognized by adding a reference to the legally binding Chart of Fundamental Rights( Charte des droits fondamentaux, 2010, pp. 391404)

The main economic trends of the labour market and societal underlying pillar and the approach which should contribute to this, and the most relevant legal acquisat EU are two important documents on the future of social security law in the European Union(European Union, 2016).

Even if it has not this name such an idea exists on other continents, such as Africa where it is considered necessary to identify a change in the social security level or to combat poverty(Badat, et al., 2015, pp. 135-187), or in Latin America where the concept,piso de protección social"plays the role of organizer of social protection policies(Casal \& Bertranou, 2014, p. 27).

Pillar purpose is to express a number of key principles for supporting the operation of fair and equitable labour markets and social protection systems, pillar will be able to rely on existing social acquis of the EU and to complete it, and the principles contained in it will put particular emphasis on addressing the needs and challenges facing the euro area. Once established, the pillar should become a frame of reference for verifying employment and social performance of the workforce participating Member States, to stimulate national reforms.

The proposal is structured around three main themes (axles):

- Equal opportunities and access to employment, including skills development and lifelong learning and active support for employment to increase employability, facilitating transitions between different statuses, and improved employability. 
- fair working conditions, to establish an appropriate balance and reliability of rights and obligations between employers and employees and between flexibility and security to facilitate the creation of jobs, the ability to absorb employment and adaptability of enterprises and promoting social dialogue.

- adequate social protection and sustainable, as well as access to essential services of high quality, including health care and long-term care in order to ensure a dignified life and protection against risk and to enable citizens to participate fully in the labour market and, more broadly, in society.

Thus, a number of policy areas were identfied, which are attached to different principles. These principles have as a starting point a series of rights already enshrined in EU law and in other relevant sources of law and establish more detailed rules for the operation ofits possibility.

These formulas are also inspired from existing EU guidelines, for example in the context of economic policy coordination, trying at the same time, take into account the latest trends.

All three of these guidelines are based on specific principles to guide their applicability and concretely implemented in various documents.

For each of these principles, the situation in Europe varies greatly and there are many practical difficulties, large and small, to address them.

We propose an analysis of the most relevant principles for European pillar of social rights, without claiming to exhaust the whole problem.

The principles have both a constructive role and a role capitalizing one system of law in that they comprise the objective requirements of society, requirements specific manifestations in the process of establishing European social rights.

Among these principles, which manifest differently in the realization of such an approach may be mentioned:

The principle of equality requires, first, anti-discrimination, ie equal treatment of parties in identical situations and comparable. It is provided by applications, even the text of the Community Treaties. Thus, Article 119 of the EC prohibits gender discrimination by applying the principle that men and women should receive equal pay for equal work, Article 7 of the EC ban on discrimination on grounds of nationality.

The concept of discrimination covers those situations where unequal treatment of nationals of different countries is due to differences between the legislations of Member States, differences in treatment may be permitted, for example if the national language is necessary to know for the exercise of certain professions.

Since December 1999, the European Council has highlighted the need to encourage the development of the conditions for a common labour market through the drafting of the Guidelines on Work Commitment for the Year 2000 adopted in Helsinki of policies aimed at combating discrimination against certain groups, such as ethnic minorities.

With the recent concerns of the European Union in the field of the ratification of free access and equality of opportunity and treatment of Community citizens, mention should be made of the Council Directive on the application of the principle of equal treatment between persons Irrespective of racial or ethnic origin.

At the same time, in applying the principle of equal treatment the Community's tendency to eliminate inequalities and to promote equality between men and women and to eliminate obvious flaws(Rîcheveaux \& Țop, 2007, p. 95). 
Council Directive 2000/78 / EC of 27 November 2000 establishing a general framework for equal treatment in employment and working conditions aims to provide uniform regulation to ensure equality of opportunity and treatment in developing relations work is completed Directive 86 / 378CEE on / application of the principle of equal treatment between men and women in occupational social security schemes(Tुop, 2009, p. 27).

With regards to the application of the principle of equality, in its many aspects, one must recall the principle of equal pay, which was enshrined and developed by a series of directives which extended it in the field of social security.

Each Member State shall ensure the application of the principle of equal pay for men and women for the same work or work of equal value.

Equal remuneration, without discrimination on grounds of sex, implies:

(A) remuneration for the same work paid for by the task shall be established on the basis of the same unit of measurement;

(B) the remuneration for work paid at the time is the same for the same workstation.

In order to ensure full equality between men and women in working life, the principle of equal treatment does not prevent a Member State from maintaining or adopting measures providing for specific advantages to facilitate the exercise of equal treatment. A professional activity by the under-represented sex or to prevent or compensate for disadvantages in the professional career.

Flexicurity is the concept(Ticlea, 2008, pp. 11-16) whereby the European Union aims to adapt to the European labour market challenges of globalization and aging. It requires a more flexible approach to hiring and firing concerns into national legislation, policy change rigid labour markets practices in Member States.

From the concept of teacher dutch Ton Wilthagen, who coined the word "flexicurity", this term could be defined as a political concept and strategically used to produce innovations social and political (including in the field of collective bargaining) as it is presented as a time positive or beneficial concept in both cases (Wilthagen, 1998, p. 2).

Blocks of flexicurity are(Vandamme, 2007, pp. 28-32):

- Adapting labour law to facilitate contractual arrangements;

- The existence of appropriate labour market policies to facilitate access to employment, maintaining them or return to service;

- Investment in continuing vocational training as a means of preserving jobs;

- Social protection measure, among others, to secure professional transitions.

The flexibility of labor relations is a constant subject of discussions between the social partners(Rîcheveaux \& Țop, 2007, p. 110). It is also a modern vision for a modern labor market.

Social solidarity is the principle that the whole community participates in supporting vulnerable people requiring support and social protection measures to overcome situations of difficulty or limitation in order to ensure social inclusion of this population(Ţop, 2016, p. 295).

The preamble to the Charter of Fundamental Rights provides that "the Union shall be founded on the indivisible and universal values of human dignity, freedom, equality and solidarity. Besides this document contains a chapter (title 4) on solidarity which contains a number of rights and principles directly related to the social field. 
Social dialogue is a voluntary process through which the social partners inform, consult and negotiate in order to establish agreements on issues of common interest. Forms of social dialogue: negotiation, consultation, information, joint management, to harmonize the interests of employers with those of employees at the unit level up to national level.

Directive 2002/14 / EC of 11 March, 2002 established a general framework for informing and consulting employees in the European Community is to establish a general framework laying down minimum requirements for the right to information and consultation of workers in Community undertakings or establishments(Official Journal, 2002, pp. 19-34).

A key issue is the freedom of the worker to represent their collective interests. Work is not a commodity. Behind labour costs, we find human beings for whom work is a source of family existence. Global expansion must find the means to provide decent work opportunities where people live, rather than lead people to an informal economy or to massive emigration.

In accordance with national laws and practices, the European Union shall have the right to negotiate and conclude collective agreements at the appropriate levels and, in the case of conflicts of interest, to take collective action to defend their interests, including strike.

In accordance with the subsidiarity principle, Member States are primarily responsible for defining social policy and employment. These policies include labour and organization of social protection systems.

Such jurisdiction is recognized in the EU treaties, from the founding of the European Economic and provide a role for the EU to complement Member States. Article 3 of the Treaty on European Union reflects this objective overview which provides that the Union "shall work for the sustainable development of Europe based on balanced economic growth and price stability, a social market economy with highly competitive, aiming at full employment of labour and social progress and a high level of protection and improvement of the environment ".

The Charter of Fundamental Rights, in the preamble that the Union is based on the indivisible and universal values of human dignity, freedom, equality and solidarity; It is based on the principle of democracy and the rule of law.

It places the person at the heart of its action by instituting citizenship of the Union and by creating an area of freedom, security and justice ", and that, by making them more visible in a Charter, it is necessary to strengthen the protection of fundamental rights in the light of social change, social progress and scientific and technological developments."

Social rights are also recognized by the addition of a legally binding reference to the Charter of Fundamental Rights. The Charter contains a chapter (title 4) on solidarity containing a number of rights and principles directly related to the Charter of Fundamental Rights. Such as the right to information and consultation of workers within the undertaking, the right to negotiate collective agreements and to resort to collective action, the right to access a free employment service, the right to be protected from unjustified dismissal, the right of access to social security benefits and social services, etc.

Social protection is the principle of the protection of employees provides for multilateral protection of workers from the point of view of all aspects related to working conditions, which lead to the elaboration of European social law.

According to (Verkindt, 2003, pp. 82-89), the issue of occupational safety and health has been an important concern within the European Union, principles in this sense being found in the constituent treaties of the European Communities, but also in a series of Directives adopted under These. 
The most important is Council Directive No. 89/391 EEC. Concerning the introduction of measures to improve the safety and health of workers at work. It is the framework document for occupational safety and health. It contains general principles concerning the prevention of occupational hazards and the protection of safety and health, the elimination of risk and accident factors, information, consultation, balanced participation in accordance with national legislation, the training of workers and their representatives, as well as general guidelines for the implementation of these principles.

\section{Conclusions}

Worldwide, the European Union (EU) is undoubtedly a model for social protection systems. Unemployment, state of health, disability, family situation, aging are all sources of precariousness to which these systems can cope. They also guarantee access to many services essential to human dignity. The Member States are responsible for organizing and financing social protection systems.

However, the EU has a particular role to play, through its legislation which coordinates national social security systems, in particular as regards mobility within the Community area. Recently, the EU has also committed itself to promoting closer collaboration between Member States on the modernization of social protection systems facing similar challenges across the EU.

Deranty \& Millan (2003) found that decent work is based on the belief that work is a source of personal dignity, family stability, community peace and democracy, economic growth that increases opportunities for productive employment and enterprise development (pp. 147184)

Decent work is a development strategy that recognizes the central role of work in people's lives: a productive jobs and bringing remuneration fair, security in the workplace and social protection of the family, the best prospects for personal development and social integration, freedom claims of expression, the ability to organize and participate in the decision process, equal opportunities and fair treatment for all men and women.

Decent work is the very essence of the strategy of global, national and local, in favor of economic and social progress, contributes heavily to the fight against poverty, unemployment and social exclusion and sustainable development, besides being in itself important.

Conclusions. The role of these principles is crucial to achieving the goals set for the future of social security law.

Pillar should contribute to the modernization, expansion and deepening of social rights in the workplace and in society by facilitating effective in absorbing and by promoting practices that can be advantageous in terms of personnel from a business perspective and from the point of societal views.

Social modern policies should be based on investment in human capital, based on equality, prevention and protection against social risks, availability of safety devices and effective incentives to access the labour market, so citizens can lead a decent life, to change their personal and professional status throughout their life and the most of their talent. 


\section{Asia Pacific Journal of Contemporary Education and Communication Technology \\ ISBN (eBook): 9780994365682 | ISSN : 2205-6181 \\ Year: 2017, Volume: 3, Issue: 2}

\section{References}

i. Badat, F. et al., 2015. The evolution and futureof social security in Africa: An actuarial perspective. Economía Española y Protección Social, Volume VIII, pp. 135-187.

ii. Casal, H. S. P. \& Bertranou, F., 2014. El Papel de los Pisos de Protección Social en América Latina y el Caribe. Lima: OIT.

iii. Charte des droits fondamentaux, 2010. Charte des droits fondamentaux. Luxembourg: Office des publications de l'Union européenne.

iv. Deranty, J.-P. \& Millan, C. M., 2003. Qu'est-ce qu'un « travail décent » ? Propositions pour élargir la campagne de l'OIT pour le travail décent à partir de la psychodynamique. Travailler. Philosophie et travail, 2(30), pp. 147-174.

v. European Union, 2016. Commission staff working document 'Main economic trends of employment labour and, s.l.: European Union.

vi. Official Journal, 2002. Official Journal. Official Journal, Issue 80, pp. 29-34.

vii. $\quad$ Rîcheveaux, M. \& Țop, D., 2007. Les grands principes du droit communautaire de travail. 8th ed. Paris: s.n.

viii. Rîcheveaux, M. \& Țop, D., n.d. La protection des droits des travailleurs dans l'Union Européenne. 8 ed. Paris: Harmattan.

ix. Tiiclea, A., 2008. New discussions about flexicurity. Romanian Labour Magazine, Volume 1, pp. 11-16.

x. Ţop, D., 2009. European Social Law. Targoviste: Bibliotheca Publishing House.

xi. Ţop, D., 2016. Social security law. 2nd ed. Târgovişte: Zven publishing House.

xii. Vandamme, F., 2007. Flexecunte: Ou vat-on?L'interet pour Ies travailleurs pauvres ? L'interet pour la modele social europeen. Romanian Labour Magazine, Volume 4, pp. 28-32.

xiii. Verkindt, P. Y., 2003. La santé au travail. Quelques rèperes pour un droit en mouvement, Mars: Droit Ouvrier.

xiv. Wilthagen, T., 1998. Flexicurity: A New Paradigm for Labour Market Policy Reform. 1 ed. Berlin: Wissenschaftszentrum. 